\title{
Leptin-Responsive GABAergic Neurons Regulate Fertility through Pathways That Result in Reduced Kisspeptinergic Tone
}

\author{
Cecilia Martin, ${ }^{1 *}$ Víctor M. Navarro, ${ }^{1 \star}$ Serap Simavli, ${ }^{1}$ Linh Vong, ${ }^{2}$ Rona S. Carroll, ${ }^{1}$ Bradford B. Lowell, ${ }^{2}$ \\ and Ursula B. Kaiser ${ }^{1}$ \\ ${ }^{1}$ Division of Endocrinology, Diabetes and Hypertension, Department of Medicine, Brigham and Women's Hospital and Harvard Medical School, Boston, \\ Massachusetts 02115, and 2Division of Endocrinology, Department of Medicine, Beth Israel Deaconess Medical Center and Harvard Medical School, Boston, \\ Massachusetts 02115
}

The adipocyte-derived hormone leptin plays a critical role in the central transmission of energy balance to modulate reproductive function. However, the neurocircuitry underlying this interaction remains elusive, in part due to incomplete knowledge of first-order leptin-responsive neurons. To address this gap, we explored the contribution of predominantly inhibitory (GABAergic) neurons versus excitatory (glutamatergic) neurons in the female mouse by selective ablation of the leptin receptor in each neuronal population: VgatCre;Lepr ${ }^{\text {lox/lox }}$ and Vglut2-Cre;Lepr ${ }^{\text {lox/lox }}$ mice, respectively. Female Vgat-Cre;Lepr ${ }^{\text {lox/lox }}$ but not Vglut2-Cre;Lepr ${ }^{\text {lox/lox }}$ mice were obese. Vgat-Cre;Lepr ${ }^{\text {lox/lox }}$ mice had delayed or absent vaginal opening, persistent diestrus, and atrophic reproductive tracts with absent corpora lutea. In contrast, Vglut2-Cre; Lepr ${ }^{\text {lox/lox }}$ females exhibited reproductive maturation and function comparable to Lepr ${ }^{l o x / l o x}$ control mice. Intracerebroventricular administration of kisspeptin-10 to Vgat-Cre;Lepr ${ }^{\text {lox/lox }}$ female mice elicited robust gonadotropin responses, suggesting normal gonadotropin-releasing hormone neuronal and gonadotrope function. However, adult ovariectomized Vgat-Cre; Lepr $^{\text {lox/lox }}$ mice displayed significantly reduced levels of Kiss 1 (but not Tac2) mRNA in the arcuate nucleus, and a reduced compensatory luteinizing hormone increase compared with control animals. Estradiol replacement after ovariectomy inhibited gonadotropin release to a similar extent in both groups. These animals also exhibited a compromised positive feedback response to sex steroids, as shown by significantly lower Kiss1 mRNA levels in the AVPV, compared with Lepr ${ }^{\text {lox/lox }}$ mice. We conclude that leptin-responsive GABAergic neurons, but not glutamatergic neurons, act as metabolic sensors to regulate fertility, at least in part through modulatory effects on kisspeptin neurons.

Key words: female; GABA; glutamate; leptin; metabolism; reproduction

\section{Introduction}

Reproduction is an essential function in mammalian physiology, with an elevated energy demand that is exquisitely regulated by

Received July 12, 2013; revised March 5, 2014; accepted March 25, 2014

Author contributions: C.M., V.M.N., L.V., R.S.C., B.B.L., and U.B.K. designed research; C.M., V.M.N., and S.S. performed research; L.V., B.B.L., and U.B.K. contributed unpublished reagents/analytic tools; C.M., V.M.N., and U.B.K. analyzed data; C.M., V.M.N., R.S.C., and U.B.K. wrote the paper.

This work was supported by the Eunice Kennedy Shriver National Institute of Child Health and Human Development through cooperative agreement U54HD028138 as part of the Specialized Cooperative Centers Program in Reproduction and Infertility Research, and by Grants R21HD066495 and R01HD019938 to U.B.K., by R01DK089044, P30DK046200, and P30DK057521 to B.B.L., by K99HD071970 to V.M.N., and by T32DK007529 and R21HD066495-S1 and the Microgrant Program from The Biomedical Research Institute and the Center for Faculty Development and Diversity's Office for Research Careers at the Brigham and Women's Hospital to C.M. We thank Kaiser Laboratory members for helpful discussions, as well as Shuyun Xu and Zongfang Yang for technical support and valuable comments on the development of this work, and Dr Andrew Wolfe for assistance with LH and FSH hormone measurements, and the Harvard Medical School Rodent Pathology Core.

The authors declare no competing financial interests.

${ }^{*}$ C.M. and V.M.N. contributed equally to this work.

Correspondence should be addressed to Dr Ursula B. Kaiser, Division of Endocrinology, Diabetes and Hypertension, Brigham and Women's Hospital, Harvard Medical School, 75 Francis Street, Boston, MA 02115. E-mail: ukaiser@partners.org.

DOI:10.1523/JNEUROSCI.3003-13.2014

Copyright $\odot 2014$ the authors $\quad 0270-6474 / 14 / 346047-10 \$ 15.00 / 0$ metabolic cues. Food deprivation can delay, and even prevent, sexual maturation and disrupt fertility across species (Frisch, 1985; Ahima et al., 1996). In humans, starvation is associated with menstrual cycle disruption in females, mediated by a decrease in luteinizing hormone ( $\mathrm{LH}$ ) secretion (Welt et al., 2004) that reflects reduced activity of gonadotropin-releasing hormone $(\mathrm{GnRH})$ neurons in response to metabolic cues (Mantzoros et al., 2011). Circulating LH levels return to normal once dietary needs are addressed (Schreihofer et al., 1993; Mantzoros et al., 2011).

The hypothalamus is a hub where the metabolic and reproductive systems converge. Among multiple metabolic cues, leptin plays a critical role in the regulation of the reproductive axis and energy homeostasis (Barash et al., 1996). Mice deficient in (ob/ $o b)$ or resistant to $(d b / d b)$ leptin are obese and infertile (Coleman, 1978; Chehab et al., 1996; de Luca et al., 2005). Paradoxically, these animals exhibit a starvation phenotype despite having abundant body fat storage (Chehab, 2000). Treatment with recombinant leptin restores fertility in $o b / o b$ mice, even before significant weight loss (Chehab et al., 1996; Mounzih et al., 1997). Consequently, leptin has been recognized as a metabolic gate to 
GnRH and gonadotropin secretion, facilitating sexual maturation and fertility (Cheung et al., 1997; Holtkamp et al., 2003).

Despite the ubiquitous expression of leptin receptors, experimental data suggest that leptin action in the brain is sufficient to modulate fertility (Cohen et al., 2001). The neuron-specific restoration of the leptin receptor (Leprb) rescues obesity and infertility in $d b / d b$ mice (de Luca et al., 2005). This finding confirms previous observations in leptin-deficient female mice, which can achieve pregnancy by gonadotropin-induced ovulation, demonstrating that infertility is linked to central hypothalamic-pituitary dysfunction rather than ovarian deficiency (Israel and Chua, 2010). Interestingly, GnRH neurons do not express leptin receptors, indicating an indirect action of leptin through interneurons afferent to GnRH neurons (Quennell et al., 2009). Moreover, only a small subset of neurons that secrete kisspeptin, a potent and direct activator of GnRH secretion, express leptin receptors (Smith et al., 2006; Louis et al., 2011). Furthermore, ablation of leptin receptors in kisspeptin-secreting neurons did not affect fertility or body weight (Donato et al., 2011; Louis et al., 2011), suggesting the presence of unidentified circuits of leptinresponsive neurons involved in the metabolic control of $\mathrm{GnRH}$ neuronal activity that modulate the kisspeptinergic tone.

The goal of the present study is to identify the nature of firstorder, leptin-responsive neurons mediating the effects of energy homeostasis on reproductive function in the female mouse. To characterize these neurons as predominantly inhibitory (GABAergic) or excitatory (glutamatergic), we selectively ablated the leptin receptor in each of these neuronal populations. We report that the ablation of leptin receptors in GABAergic neurons, but not glutamatergic neurons, recapitulates the $o b / o b$ and $d b / d b$ infertility phenotype in females (Swerdloff et al., 1978; Batt et al., 1982; de Luca et al., 2005).

\section{Materials and Methods}

Animal care. The animal studies were approved by the Harvard Medical Area Standing Committee on the Use of Animals in Research and Teaching in the Harvard Medical School Center for Animal Resources and Comparative Medicine. The mice were maintained under a $12 \mathrm{~h}$ light/ dark cycle and provided with standard rodent chow and water ad libitum.

Transgenic mice. Vgat-Cre;Lepr ${ }^{\text {lox/lox }}$, and Vglut2-Cre;Lepr $r^{\text {lox/lox }}$ mouse lines were generated by gene targeting as described previously (Vong et al., 2011). In brief, Vgat ${ }^{\mathrm{Cre} / \mathrm{Cre}} ;$ Lepr $^{\text {lox/WT }}$ or Vglut2 ${ }^{\mathrm{Cre} / \mathrm{Cre}}$; Lepr ${ }^{\text {lox/lox }}$ male mice were mated with Lepr ${ }^{\text {lox/lox }}$ female mice (Balthasar et al., 2004; McMinn et al., 2004). The Vgat ${ }^{\mathrm{Cre} /+}$ mice and Vglut2 ${ }^{\mathrm{Cre} /+}$ were generated by insertion of an internal ribosome entry site (IRES)-Cre recombinase cassette downstream of the stop codon of endogenous genes Vgat (vesicular GABA transporter) and Vglut2 (synaptic vesicular glutamate transporter), respectively (Vong et al., 2011). The Lepr ${ }^{\text {lox/+ }}$ mice were generated by the insertion of two loxP sites and an frt site flanking the coding exon 17 of the leptin receptor gene (Balthasar et al., 2004; McMinn et al., 2004). This modification (Meyers et al., 1998) permits the conditional ablation of Lepr driven by the IRES-Cre recombinase cassettes described above (Balthasar et al., 2004; McMinn et al., 2004). The mice were genotyped by PCR using the following primers to identify expression of the Cre amplicon (5'-GCC CTG GAA GGG ATT TTT GAA GCA-3' and 5'-ATG GCT AAT CGC CAT CTT CCA GCA$\left.3^{\prime}\right)$, endogenous ghrelin $(G h r l)$ as internal amplification control (5'GGT CAG CCT AAT TAG CTC TGT- $3^{\prime}$ and $5^{\prime}$-GAT CTC CAG CTC CTC CTC TGT C-3'), and primers recognizing the loxP site (5'-AAT GAA AAA GTT GTT TTG GGA CGA-3' and 5'-CAG GCT TGA GAA CAT GAA CAC AAC AAC-3'). Ghrl is used as an internal amplification control when screening for the presence of Cre recombinase during the genotyping of the animals. This control excludes any potential falsenegative results when Cre recombinase is not amplified.

Puberty assessment. The following parameters were monitored in the Vgat-Cre;Lepr ${ }^{\text {lox/lox }}$, Vglut2-Cre;Lepr ${ }^{\text {lox/lox }}$, and Lepr $r^{\text {lox/lox }}$ female mice:
(1) changes in body weight, (2) progression to vaginal opening, and (3) timing of first estrus. Body weight was measured twice a week from postnatal day (P) 25 to $\mathrm{P} 40$ followed by once per week from P40 to P60, using six mice from each genotype group. Prepubertal female mice were monitored daily for vaginal opening (as indicated by complete canalization of the vagina) until P45. For this purpose, we monitored six mice for the Vglut2-Cre;Lepr ${ }^{\text {lox/lox }}$ and Lepr ${ }^{\text {lox/lox }}$ groups, followed by assessment of vaginal cytology for another $25 \mathrm{~d}$ after vaginal opening to identify the timing of first estrus and to evaluate estrous cyclicity. Of note, $12 \mathrm{Vgat}$ Cre; epr $^{\text {lox/lox }}$ females were monitored to obtain a more accurate determination of the fraction with vaginal opening. Subsequently, we further increased the number of Vgat-Cre;Lepr ${ }^{\text {lox/lox }}$ females monitored to gather a total of six Vgat-Cre;Lepr ${ }^{\text {lox/lox }}$ females with complete vaginal opening in which to assess first estrus and estrous cyclicity.

Histology. Ovaries and uteri were collected from six animals for each genotype group, weighed and fixed in Bouin's solution. The Vgat-Cre; Lepr ${ }^{\text {lox/lox }}$ mice were used independent of the vaginal opening status. The tissues were embedded in paraffin and sectioned $(10 \mu \mathrm{m})$ for hematoxylin and eosin (H\&E) staining (Harvard Medical School Rodent Pathology Core) and images acquired under $4 \times$ magnification. The ovaries were analyzed for presence and type of follicles and for presence of corpora lutea.

Kisspeptin functional assay. Mice were anesthetized with isoflurane anesthesia and received an intracerebroventricular injection (Furuta et al., 2001) of $5 \mu$ l kisspeptin-10 (Kp10, $1 \mathrm{nmol})$ or vehicle $(0.9 \% \mathrm{NaCl}$; Gottsch et al., 2004; Castellano et al., 2005). Blood samples (200 $\mu \mathrm{l})$ were collected by retro-orbital bleeding (van Herck et al., 1998) 20 min postinjection. The animals were injected with $\mathrm{Kp} 10$ or vehicle in a crossover experimental design with an interval of 1 week.

Ovariectomy. Bilateral removal of ovaries from 6- to 8-week-old naive females was performed with isoflurane anesthesia. Briefly, the ventral skin was shaved and cleaned to perform two small incisions in the skin and abdominal musculature on both sides of the abdomen. Once the gonads were identified and excised, the muscle incisions were sutured and the skin was closed with surgical clips. One week later, the mice were killed by decapitation with anesthesia, trunk blood was collected for measurement of hormone levels, and brains were rapidly removed and frozen for in situ hybridization.

Sex steroid hormone replacement. Estradiol capsules were prepared as previously described (Gill et al., 2012). In brief, Silastic capsules were filled with $20 \mu \mathrm{g} / \mathrm{ml}$ estradiol dissolved in sesame oil and were equilibrated in saline solution overnight at $37^{\circ} \mathrm{C}$. A subgroup of ovariecto-

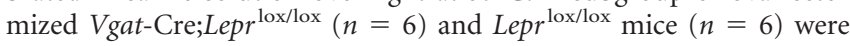
implanted with estradiol capsules under anesthesia immediately after the bilateral ovariectomy procedure. The dorsal area of the neck was shaved and cleaned to perform a small incision. A subcutaneous pocket was bluntly dissected with ample space to introduce the estradiol capsule and the wound was closed with surgical clips. The mice were killed after 1 week as described for the ovariectomy procedure.

Hormone assays. LH and follicle-stimulating hormone (FSH) levels were measured using a Milliplex MAP immunoassay (rat pituitary panel, Millipore) in the Luminex 200 (Singh et al., 2009).

In situ hybridization. The brains were collected, frozen on dry ice, and stored at $-80^{\circ} \mathrm{C}$ until sectioning. The brain sections $(20 \mu \mathrm{m}$ thick, 5 series) were mounted on SuperFrost plus slides (VWR Scientific). The Kiss 1 and Tac 2 mRNA probes were radiolabeled with ${ }^{33} \mathrm{P}$-UTP and the slides processed as described previously (Gottsch et al., 2004; Kauffman et al., 2009). The number of cells expressing Kiss1 or Tac2 was determined using ImageJ software (NIH). Kiss 1 and Tac2 mRNA expression were assessed in the arcuate nucleus (ARC) of ovariectomized animals, whereas Kiss1 mRNA was also analyzed in the anteroventral periventricular nucleus/periventricular nucleus continuum (AVPV/PeN) of ovariectomized females treated for 1 week with estradiol implants (20 $\mu \mathrm{g} / \mathrm{ml})$.

Quantitative real-time RT-PCR. Intact adult (6- to 8-week-old) VgatCre; Lepr $^{\text {lox/lox }}$ and Lepr ${ }^{\text {lox/lox }}$ (in diestrus) females were killed and brains were collected. The hypothalamic tissue was sectioned using a coronal brain matrix (Braintree Scientific) and immediately frozen in liquid nitrogen and stored at $-80^{\circ} \mathrm{C}$. Briefly, the anteroventral periventricular 
nucleus/preoptic area (AVPV/POA) was dissected by coronal cuts located caudal to the optic chiasm and rostral to the mammillary bodies followed by two lateral cuts ( $1 \mathrm{~mm}$ thick each side) from the middle line and $2 \mathrm{~mm}$ from the dura (Brown et al., 2012). Total RNA from the AVPV/POA and ARC were isolated using TRIzol reagent (Invitrogen) followed by chloroform/isopropanol extraction. RNA was quantified using NanoDrop 2000 spectrophotometer (Thermo Scientific) and one microgram of RNA was reverse transcribed using Superscript III cDNA synthesis kit (Invitrogen). Quantitative real-time PCR assays were performed on an ABI Prism 7000 sequence detection system, and analyzed using ABI Prism 7000 SDS software (Applied Biosystems). The cycling conditions were the following: $2 \mathrm{~min}$ incubation at $95^{\circ} \mathrm{C}$ (hot start), 45 amplification cycles $\left(95^{\circ} \mathrm{C}\right.$ for $30 \mathrm{~s}, 60^{\circ} \mathrm{C}$ for $30 \mathrm{~s}$, and $45 \mathrm{~s}$ at $75^{\circ} \mathrm{C}$, with fluorescence detection at the end of each cycle), followed by melting curve of the amplified products obtained by ramped increase of the temperature from 55 to $95^{\circ} \mathrm{C}$ to confirm the presence of single amplification product per reaction. The Kiss $1 r$ mRNA (primers: $5^{\prime}$-GGT GCT GGG AGA CTT CAT GT-3', and 5'-ACA TAC CAG CGG TCC ACA CT-3') was detected using SYBR green mix (Bio-Rad) according to the manufacturer's instructions. The data were normalized using cyclophilin (primers: 5'-CGA GCT CTG AGC ACT GGA GA-3' and 5'-TGG CGT GTA AAG TCA CCA CC- $3^{\prime}$ ) as an internal control, and expressed as fold-change relative to Lepr ${ }^{\text {lox/lox }}$ control.

Statistical analysis. Statistical analysis was performed using GraphPad Prism 4. Data are shown as mean \pm SEM and the significance level was set as $p<0.05$. Differences were determined using a two-tailed unpaired Student's $t$ test or an ANOVA test followed by Bonferroni post hoc testing.

\section{Results}

Generation of Vgat-Cre;Lepr ${ }^{\text {lox/lox }}$ and Vglut2-Cre;Lepr ${ }^{\text {lox/lox }}$ mice

To elucidate the identity of leptin responsive neurons that modulate the activity of the HPG axis, we generated mice with selective deletion of leptin receptor in either GABAergic neurons (Vgat-Cre;Lepr ${ }^{\text {lox/lox }}$ mice) or glutamatergic neurons (Vglut2Cre; Lepr ${ }^{\text {lox/lox }}$ mice), as previously described (Vong et al., 2011). Mice were genotyped and female Vgat-Cre; Lepr ${ }^{\text {lox/lox }}$ and Vglut2Cre; $L e p r^{\text {lox/lox }}$ mice were selected for reproductive phenotyping compared with Lepr $r^{\text {lox/lox }}$ control littermates (see Materials and Methods for details).

Metabolic and reproductive assessment of female Vgat-Cre; Lepr $^{\text {lox/lox }}$ and Vglut2-Cre;Lepr ${ }^{\text {lox/lox }}$ mice

To determine whether the mouse models being studied had the expected metabolic phenotypes, all mice were weighed frequently from age $25-60$ d. Female Vgat-Cre;Lepr ${ }^{\text {lox/lox }}$ mice exhibited a significantly greater body weight than Lepr ${ }^{\text {lox/lox }}$ control littermates beginning at PND30 (Vgat-Cre;Lepr ${ }^{\text {lox/lox }} 21.3 \pm 1.2 \mathrm{~g}$ vs Lepr ${ }^{\text {lox/lox }} 17.9 \pm 0.6 \mathrm{~g} ; F_{(55)}=3.16, p=0.0254$; Fig. $1 A$ ). This increased body weight persisted and became even greater with increasing age (Fig. 1A). In contrast, female Vglut2-Cre;Lepr ${ }^{\text {lox/lox }}$ mice showed a trend toward an increased body weight beginning at age $42 \mathrm{~d}$, but did not reach significance when compared with Lepr ${ }^{\text {lox/lox }}$ control littermates during the time of the study (Fig. $1 A$ ). These findings are consistent with a previous report (Vong et al., 2011).

To assess the reproductive phenotype of these mice, we first monitored the age of vaginal opening (VO), reflecting increased circulating estradiol levels and used as an indirect biomarker of puberty onset. The Vgat-Cre;Lepr ${ }^{\text {lox/lox }}$ females showed complete absence of VO at PND34 versus $100 \%$ of VO in Vglut2-Cre; Lepr ${ }^{\text {lox/lox }}$ and control mice at the same age (Fig. 1B). After noticing that VO rarely occurred in Vgat-Cre; Lepr ${ }^{\text {lox/lox }}$ females, we increased the number of mutant animals $(n=12)$ to monitor for VO. Only a small subset $(16.6 \%, 2$ of 12$)$ of these Vgat-Cre;
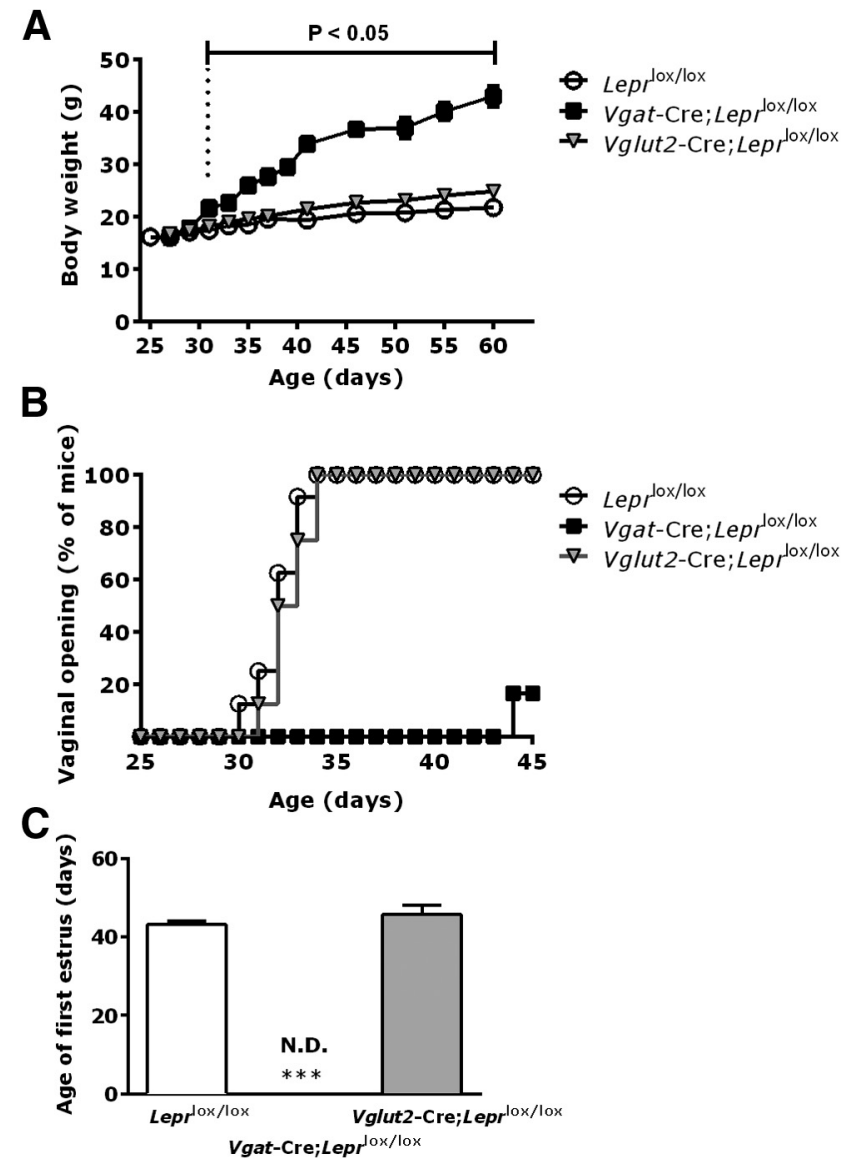

Figure 1. Leptin receptor deletion in GABAergic neurons impairs the onset of puberty in females. A, Body weight in female Vgat-Cre;Lepr ${ }^{\text {lox/lox }}$ mice (closed squares, $n=6$ ) compared with Vglut2-Cre;Lepr ${ }^{\text {lox/lox }}$ mice (gray triangles, $n=6$ ) and respective Lepr ${ }^{\text {lox/lox }}$ control littermates (open circles, $n=6$ ). Bracket indicates the age at which the body weight increase became statistically significant $(p=0.0254)$ for Vgat-Cre;Lepr ${ }^{\text {lox/lox }}$ mice. $\boldsymbol{B}$, Age of V0 for Vgat-Cre;Lepr $^{\text {lox/lox }}(n=12)$, Vglut2-Cre;Lepr ${ }^{\text {lox/lox }}(n=6)$, and Lepr ${ }^{\text {lox/lox }}$ controls $(n=6)$, expressed as percentage of total mice for each genotype. $C$, Age of first estrus ( $n=6$ for each group). Data are shown as mean $\pm \mathrm{SEM} ;{ }^{* * *} p<0.0001$, one-way ANOVA followed by Bonferroni's multiple-comparisons test. N.D., Not detected.

Lepr ${ }^{\text {lox/lox }}$ mice displayed complete VO, with a marked delay of $>2$ weeks compared with control Lepr ${ }^{\text {lox/lox }}$ mice $(47.4 \pm 2.5 \mathrm{~d}$ vs $31.6 \pm 1.0 \mathrm{~d}$, respectively; Fig. $1 B$ ). Interestingly, the age of $\mathrm{VO}$ for Vglut2-Cre;Lepr ${ }^{\text {lox/lox }}$ females $(32.1 \pm 1.0 \mathrm{~d})$ was indistinguishable from their Lepr ${ }^{\text {lox/lox }}$ littermates (Fig. $1 B$ ). In addition, we measured the age of first estrus to determine the time of initiation of ovarian cycles. The mean age of first estrus was comparable in Vglut2-Cre; Lepr ${ }^{\text {lox/lox }}$ and control Lepr ${ }^{\text {lox/lox }}$ mice (45.7 \pm $2.5 \mathrm{~d}$ vs $43.0 \pm 2.0 \mathrm{~d}$, respectively, $p=$ not significant) but first estrus was absent in Vgat-Cre;Lepr ${ }^{\text {lox/lox }}$ mice (Fig. 1C). Of note, we ultimately screened several cohorts of mice to identify a total of six Vgat-Cre; Lepr ${ }^{\text {lox/lox }}$ females with VO for assessment of estrous cyclicity.

To further explore the integrity of the hypothalamicpituitary-gonadal (HPG) axis, we monitored vaginal cytology to determine the pattern of estrous cycles for $25 \mathrm{~d}$, beginning at $42 \mathrm{~d}$ of age. Vglut2-Cre; Lepr ${ }^{\text {lox/lox }}$ and control Lepr ${ }^{\text {lox/lox }}$ mice both had normal estrous cycles, $\sim 4-5 \mathrm{~d}$ in duration (Fig. 2). We monitored vaginal cytology in the six Vgat-Cre;Lepr ${ }^{\text {lox/lox }}$ females that had achieved complete VO. These females were acyclic, remaining in diestrus throughout the period of monitoring (Fig. 2). Consistent with the presence of regular estrous cycles, the ovarian 

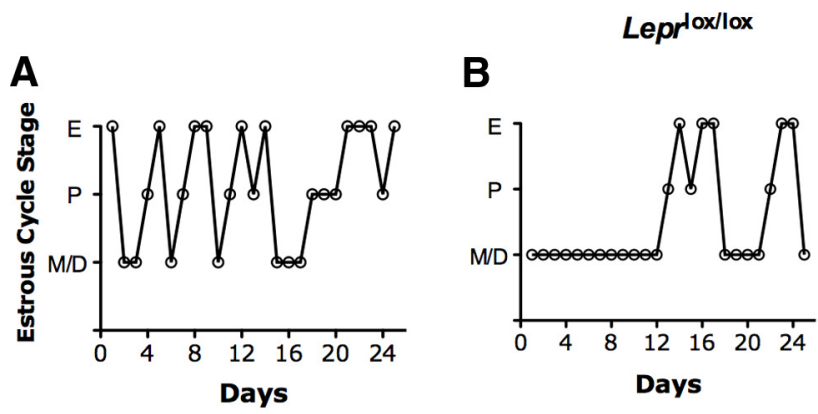

C

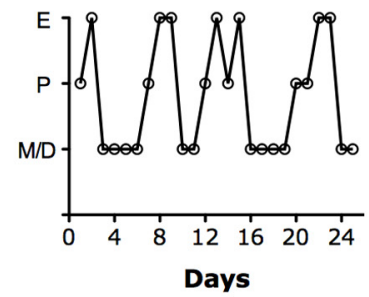

Vgat-Cre;Leprlox/lox
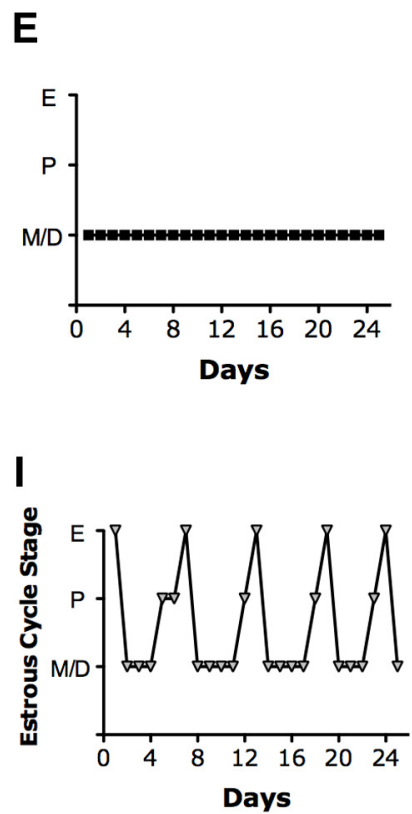

J

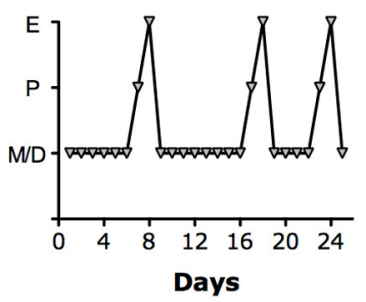

K

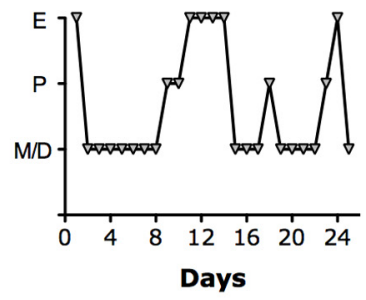

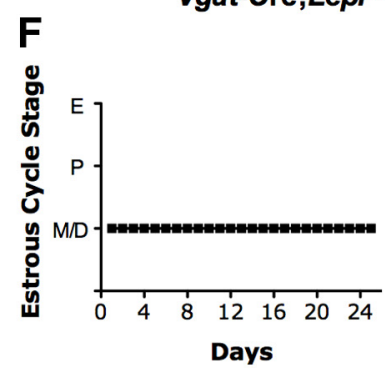

G

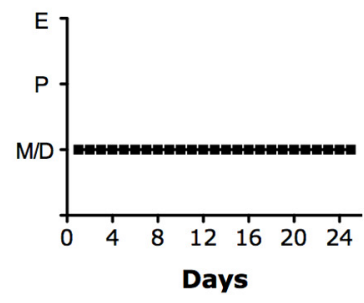

H

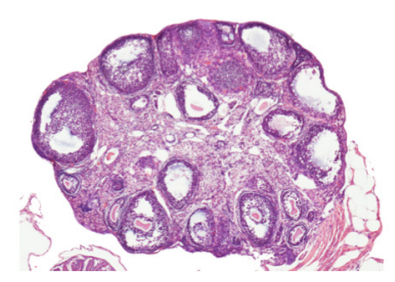

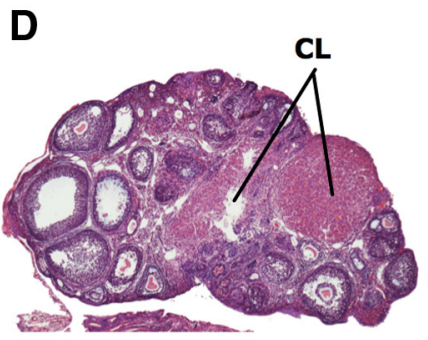

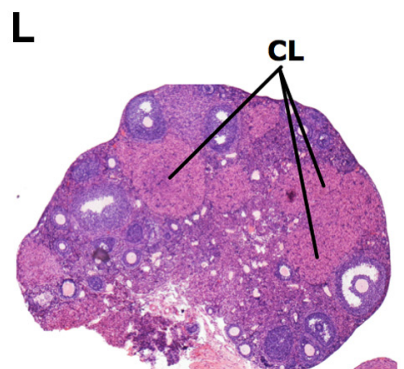

Figure 2. Vgat-Cre;Lepr ${ }^{\text {lox/lox }}$ females are acyclic. Representative estrous cycle profiles from control Lepr ${ }^{\text {lox/lox }}(\boldsymbol{A}-\boldsymbol{C})$, Vgat-Cre;Lepr ${ }^{\text {lox/lox }}(\boldsymbol{E}-\boldsymbol{G})$, and Vglut2-Cre;Lepr ${ }^{\text {lox/lox }}(\boldsymbol{I}-\boldsymbol{K})$ mice. The

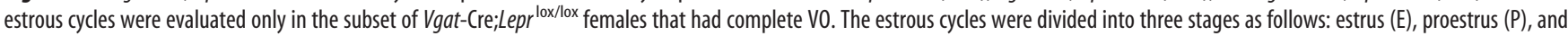
metestrus/diestrus (M/D). In addition, representative images of ovarian H\&E-stained cross-sections are shown from control Lepr lox/lox $(\boldsymbol{D})$, Vgat-Cre;Lepr $^{\text {lox/lox }}(\boldsymbol{H})$, and Vglut2-Cre;Lepr lox/lox $(\boldsymbol{L})$ mice. CL, Corpus luteum.

histology of Vglut2-Cre;Lepr ${ }^{\text {lox/lox }}$ and control Lepr ${ }^{\text {lox/lox }}$ mice (killed in diestrus) revealed numerous follicles at different stages of maturation, from primary follicles to antral follicles. In addition, multiple corpora lutea were present, confirming that ovulation had occurred (Fig. 2). In contrast, ovaries from Vgat-Cre; Lepr ${ }^{\text {lox/lox }}$ showed follicles at various stages of development (both healthy and atretic) but absent corpora lutea (Fig. 2), consistent with the absence of estrous cyclicity and consequently no ovulation.

Consistent with the lack of VO in the majority of Vgat-Cre; Lepr ${ }^{\text {lox/lox }}$ mice, the reproductive tracts from Vgat-Cre;Lepr ${ }^{\text {lox/lox }}$ mice were atrophic, with markedly decreased uterine (33.2 \pm 5.8 $\mathrm{mg})$ and ovarian (13.8 $\pm 1.8 \mathrm{mg}$ ) weights compared with Vglut2Cre; Lepr $^{\text {lox/lox }}$ and control Lepr ${ }^{\text {lox/lox }}$ mice uteri $(80.8 \pm 1.8 \mathrm{mg}$ and $71.7 \pm 5.6 \mathrm{mg}$, respectively; $\left.F_{(2,17)}=28.81, p<0.0001\right)$ and ovaries $\left(27.5 \pm 2.0 \mathrm{mg}\right.$ and $26.5 \pm 1.0 \mathrm{mg}$, respectively: $F_{(2,14)}=$ $19.29, p<0.0001$ ) in diestrus (Fig. 3).

Response to central administration of kisspeptin-10 in Vgat-Cre;Lepr ${ }^{\text {lox/lox }}$ females

Based on the impaired pubertal maturation of Vgat-Cre;Lepr ${ }^{\text {lox/lox }}$ female mice, combined with their lack of estrous cyclicity and absence of ovarian corpora lutea (Figs. 1-3), we hypothesized that these mice, but not the Vglut2-Cre;Lepr ${ }^{\text {lox/lox }}$ female mice, have impaired central activation of the HPG axis. Prior evidence that leptin acts centrally through impaired hypothalamicpituitary function to cause reproductive defects provides further support for this hypothesis (Swerdloff et al., 1978; Cohen et al., 2001). The absence of leptin receptors in GnRH neurons (Quennell et al., 2009; Louis et al., 2011) suggests that the effect on the reproductive phenotype in the Vgat-Cre;Lepr ${ }^{\text {lox/lox }}$ female mice occurs indirectly, through neurons upstream of the GnRH neurons. To test whether the GnRH system is intact in these animals, we injected 2-month-old Vgat-Cre;Lepr ${ }^{\text {lox/lox }}$ female mice and control littermates $\left(\right.$ Lepr $\left.^{\text {lox/lox }}\right)$ centrally (intracerebroventricularly) with $1 \mathrm{nmol} \mathrm{Kp10,} \mathrm{the} \mathrm{most} \mathrm{potent} \mathrm{activator} \mathrm{of} \mathrm{GnRH}$ neurons identified to date (Gottsch et al., 2004), or vehicle (saline). Blood samples were collected $20 \mathrm{~min}$ postinjection for measurement of serum LH and FSH. As shown in Figure 4, the response of Vgat-Cre;Lepr ${ }^{\text {lox/lox }}$ females to kisspeptin was not only preserved, but was even augmented, with a robust 20 -fold increase in serum LH levels (vehicle: $0.4 \pm 0.1 \mathrm{ng} / \mathrm{ml}$ vs Kp10: $\left.10.0 \pm 1.8 \mathrm{ng} / \mathrm{ml} ; t_{(12)}=6.24, p=0.0005\right)$, and an almost twofold increase in FSH levels (vehicle: $0.7 \pm 0.1 \mathrm{ng} / \mathrm{ml}$ vs Kp10: $1.3 \pm 0.1$ $\left.\mathrm{ng} / \mathrm{ml} ; t_{(13)}=2.19, p=0.0469\right)$, whereas the control Lepr ${ }^{\text {lox/lox }}$ group had only a sixfold increase in LH levels (vehicle: $0.5 \pm 0.1$ $\mathrm{ng} / \mathrm{ml}$ vs Kp10: $\left.3.2 \pm 0.9 \mathrm{ng} / \mathrm{ml} ; t_{(12)}=2.73, p=0.0182\right)$, together with a twofold increase in FSH levels (vehicle: $0.5 \pm 0.1$ 

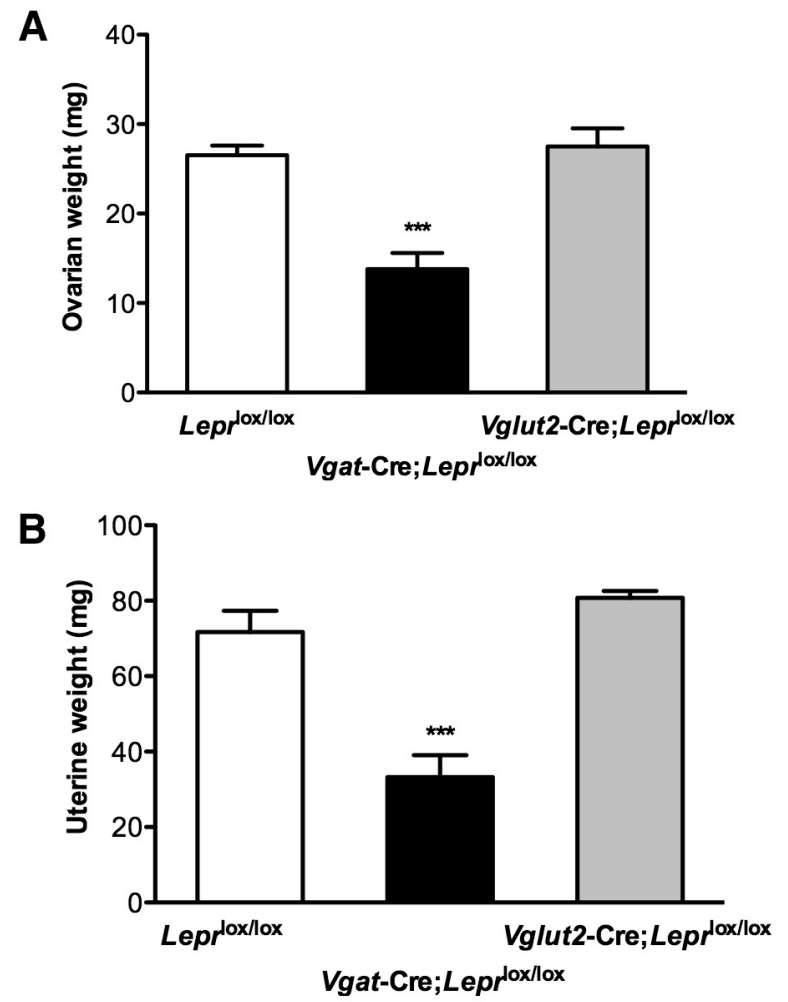

C

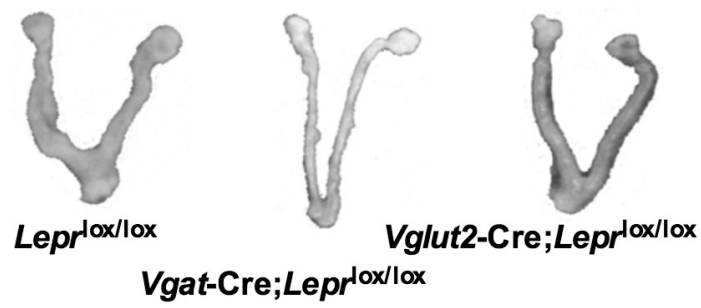

Figure 3. Vgat-Cre;Lepr ${ }^{10 x / 10 x}$ females have reduced ovarian and uterine weights. $A$, Ovarian and $(\boldsymbol{B})$ uterine weights of Lepr ${ }^{\text {lox/lox }}$ control mice (white bar, $N=10$ ), Vgat-Cre;Lepr ${ }^{\text {lox/lox }}$ mice (black bar, $N=6$ ), and Vglut2-Cre;Lepr ${ }^{\text {lox/lox }}$ mice (gray bar, $N=6$ ). Data are expressed as mean $\pm \mathrm{SEM} ;{ }^{* * *} p<0.0001$, one-way ANOVA followed by Bonferroni's multiplecomparisons test. C, Representative pictures of uteri and ovaries from control Lepr ${ }^{\text {lox/lox }}$, VgatCre;Lepr ${ }^{\text {lox/lox }}$, and Vglut2-Cre;Lepr ${ }^{\text {lox/lox }}$ mice killed during diestrus at age 2 months.

$\mathrm{ng} / \mathrm{ml}$ vs Kp10: $\left.1.0 \pm 0.1 \mathrm{ng} / \mathrm{ml} ; t_{(12)}=3.12, p=0.0089\right)$. Moreover, the magnitude of LH response to Kp10 stimulus was significantly increased in Vgat-Cre;Lepr ${ }^{\text {lox/lox }}$ females compared with Lepr ${ }^{\text {lox/lox }}$ females (Vgat-Cre;Lepr ${ }^{\text {lox/lox }} 10.0 \pm 1.8 \mathrm{ng} / \mathrm{ml}$ vs Lep$\left.r^{\text {lox } / \mathrm{lox}}: 3.2 \pm 0.9 \mathrm{ng} / \mathrm{ml} ; F_{(1,23)}=16.63, p=0.0005\right)$, whereas FSH levels remain unaffected (Vgat-Cre;Lepr ${ }^{\text {lox/lox}}: 1.3 \pm 0.1 \mathrm{ng} / \mathrm{ml}$ vs Lepr ${ }^{\text {lox } / \mathrm{lox}}: 1.0 \pm 0.1 \mathrm{ng} / \mathrm{ml} ; F_{(1,18)}=0.05, p=$ N.S. $)$. These results confirm that $\mathrm{GnRH}$ neuronal and gonadotrope function are intact, and suggest that the defect is upstream of GnRH neurons.

It is plausible to attribute the augmented response to kisspeptin in the Vgat-Cre;Lepr ${ }^{\text {lox/lox }}$ females to a compensatory increase in kisspeptin receptor (Kiss1r) levels, as previously described in states of negative energy balance (Castellano et al., 2005). To investigate this premise, we collected hypothalamic tissue from the preoptic area, where GnRH neurons expressing Kiss1r are located, from intact adult females (Lepr ${ }^{\text {lox/lox }}$ females were killed in diestrus) and quantified the Kiss1r gene expression by quantitative RT-PCR. We found no significant difference in Kiss1r mRNA levels in the preoptic area $(p=0.3014$, data not shown), suggesting that other mechanisms were responsible for the augmented kisspeptin response.

The effects of ovariectomy and of estrogen replacement on serum gonadotropins in Vgat-Cre;Lepr ${ }^{\text {lox/lox }}$ female mice To further explore the reproductive role of GABAergic leptin responsive neurons, we investigated the ability of Vgat-Cre; Lepr ${ }^{\text {lox/lox }}$ mice to respond to the negative feedback effects of sex steroids. To this end, we ovariectomized (OVX) 6- to 8-week-old Vgat-Cre;Lepr ${ }^{\text {lox/lox }}$ females and their corresponding control littermates and replaced them with either empty capsules or with capsules filled with estradiol $(20 \mu \mathrm{g} / \mathrm{ml})$. One week after surgery, blood samples were collected and serum LH and FSH levels were measured. Vgat-Cre;Lepr ${ }^{\text {lox/lox }}$ females were able to respond to ovariectomy with a compensatory rise in serum LH levels (intact $0.4 \pm 0.1 \mathrm{ng} / \mathrm{ml}$ vs OVX $\left.3.2 \pm 0.2 \mathrm{ng} / \mathrm{ml} ; t_{(12)}=5.08, p=0.0003\right)$, as did control Lepr ${ }^{\text {lox/lox }}$ females (intact $0.5 \pm 0.1 \mathrm{ng} / \mathrm{ml}$ vs OVX $\left.4.3 \pm 0.4 \mathrm{ng} / \mathrm{ml} ; t_{(10)}=8.63, p<0.0001\right)$. Similarly, the VgatCre; Lepr ${ }^{\text {lox/lox }}$ female mice responded to ovariectomy with an increase in serum FSH levels (intact $0.8 \pm 0.1 \mathrm{ng} / \mathrm{ml}$ vs OVX $\left.5.3 \pm 0.7 \mathrm{ng} / \mathrm{ml} ; t_{(12)}=7.42, p<0.0001\right)$, as did Lepr ${ }^{\text {lox } / \mathrm{lox}}$ females (intact $0.5 \pm 0.1 \mathrm{ng} / \mathrm{ml}$ vs OVX $6.5 \pm 0.9 \mathrm{ng} / \mathrm{ml} ; t_{(11)}=$ 7.08, $p<0.0001$; Fig. $5 A, B)$. Interestingly, the extent of the $\mathrm{LH}$ response to OVX in Vgat-Cre;Lepr ${ }^{\text {lox/lox }}$ females was significantly reduced compared with control Lepr ${ }^{\text {lox/lox }}$ littermates (Vgat-Cre; Lepr $^{\text {lox } / \mathrm{lox}} 3.2 \pm 0.2 \mathrm{ng} / \mathrm{ml}$ vs Lepr ${ }^{\text {lox } / \mathrm{lox}} 4.3 \pm 0.4 \mathrm{ng} / \mathrm{ml} ; F_{(1,20)}=$ $5.14, p=0.0346)$.

The previous experiment showed a significantly reduced ability of $\mathrm{Vgat}$-Cre; Lepr ${ }^{\text {lox/lox }}$ animals to respond to the lack of circulating sex steroids. To expand the characterization of the negative feedback in these mice, an additional set of OVX and estradiolreplaced $(\mathrm{OVX}+\mathrm{E} 2)$ animals was compared. In this experiment, plasma LH and FSH levels were significantly reduced in both Vgat-Cre;Lepr ${ }^{\text {lox/lox }}$ mice and littermate controls $(p<0.0001$, data not shown) after estradiol treatment, compared with OVX mice. Importantly, E2-treated Vgat-Cre;Lepr ${ }^{\text {lox/lox }}$ females had significantly lower LH and FSH levels compared with their corresponding controls (LH: Vgat-Cre;Lepr ${ }^{\text {lox/lox }} 0.23 \pm 0.03 \mathrm{ng} / \mathrm{ml}$ vs $L e p r^{\text {lox/lox }} 0.9 \pm 0.2 \mathrm{ng} / \mathrm{ml}, t_{(8)}=3.84, p=0.0049 ; \mathrm{FSH}$ : VgatCre; Lepr $^{\text {lox } / \text { lox }} 2.4 \pm 0.5 \mathrm{ng} / \mathrm{ml}$ vs $L e p r^{\text {lox } / \text { lox }} 7.13 \pm 1.3 \mathrm{ng} / \mathrm{ml}$, $t_{(10)}=3.25, p=0.0086$; Fig. $\left.5 C, D\right)$.

Hypothalamic Kiss1 and Tac2 expression in Vgat-Cre;Lepr ${ }^{\text {lox/lox }}$ females

In the previous experiment, Vgat-Cre;Lepr ${ }^{\text {lox/lox }}$ mice had lower serum LH levels after gonadectomy compared with controls (Fig. $5 A$ ). Previous reports in food deprived rats and leptin deficient $(o b / o b)$ mice showed a significant reduction in hypothalamic Kiss 1 mRNA levels in the arcuate nucleus (ARC). These findings correlated with reduced $\mathrm{LH}$ secretion under these conditions, implying that leptin may act as an upstream regulator of Kiss1 gene expression (Castellano et al., 2005; Smith et al., 2006; Quennell et al., 2011). To investigate whether the decreased LH response to ovariectomy observed in Vgat-Cre;Lepr ${ }^{\text {lox/lox }}$ mice is mediated by an impaired response of kisspeptin neurons to the negative feedback of sex steroids, we analyzed by in situ hybridization the mRNA levels of two key players in the ARC, the hypothalamic area suggested as key to the negative feedback of sex steroids in the control of the tonic GnRH secretion: kisspeptin (Kiss1) and its cotransmitter, neurokinin B (Tac2). The numbers of cells in the ARC expressing Kiss1 and Tac2 were quantified 1 week post-OVX in Vgat-Cre;Lepr $r^{\text {lox/lox }}$ and control Lepr $r^{\text {lox/lox }}$ mice, based on previous reports indicating maximal expression 


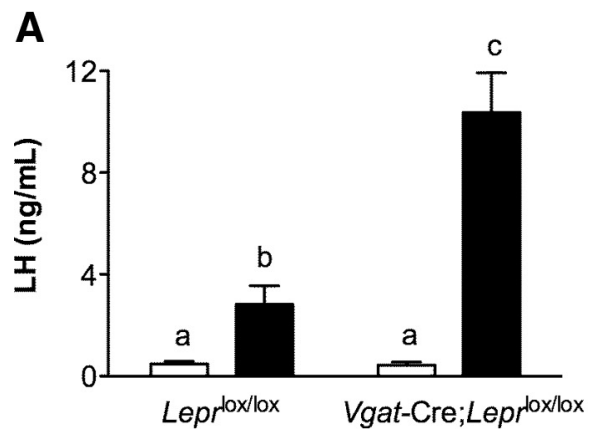

B

Figure 4. Increased LH response to central administration of kisspeptin in V gat-Cre;Lepr ${ }^{\text {lox/lox }}$ females. $\boldsymbol{A}$, Serum LH and (B) serum FSH levels 20 min after central intracerebroventricular injection of Kp10 (black bars) or vehicle (white bars) using a crossover experimental design with a 1 week interval in Lepr ${ }^{\text {lox/lox }}(n=6)$ and Vgat-Cre;Lepr ${ }^{\text {lox/lox }}(n=6)$ female mice. Data are shown as mean \pm SEM. Lowercase letters $a$-c above the bars indicates statistically significant differences among groups ( $p<0.05$, one-way ANOVA followed by the Student-Newman-Keuls multiple range test).

A

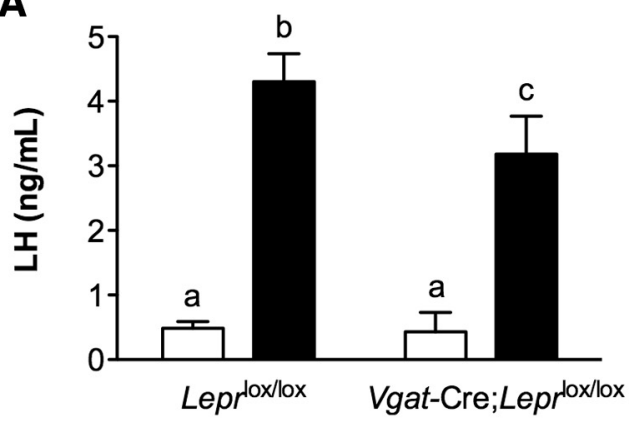

C

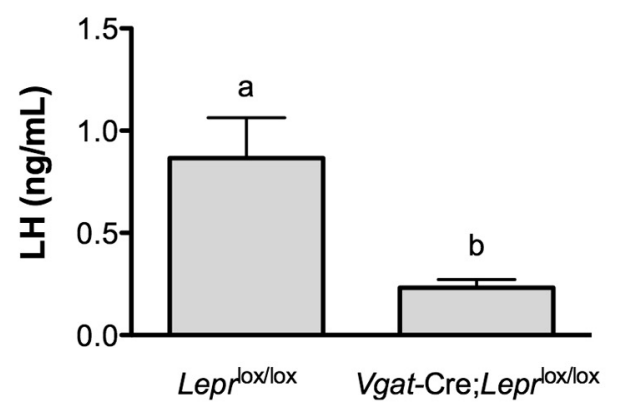

B

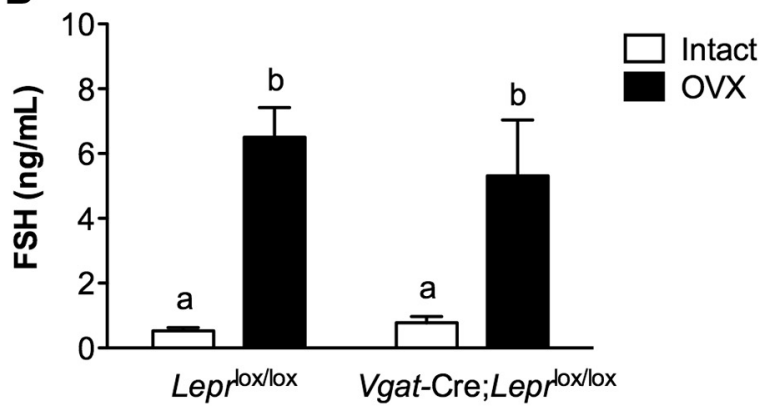

D

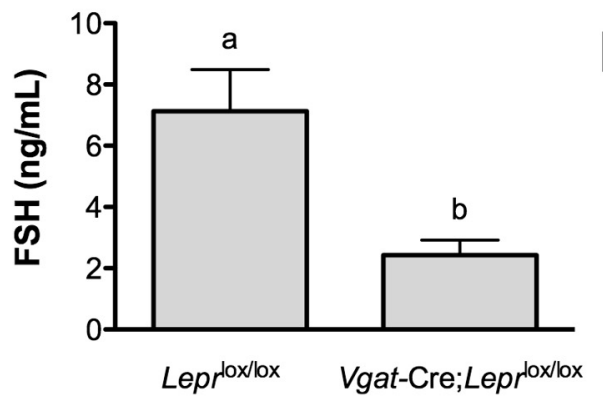

Figure 5. The compensatory increase in gonadotropins in response to bilateral ovariectomy is reduced in Vgat-Cre;Lepr ${ }^{\text {lox/lox }}$ females. $\boldsymbol{A}$, Serum LH and (B) Serum FSH levels prior (white bars) and 1 week after OVX (black bars) in Lepr ${ }^{\text {lox/lox }}(n=6)$ and Vgat-Cre; Lepr ${ }^{\text {lox/lox }}(n=6)$ mice. Lowercase letters $a-c$ above the bars indicate statistically significant differences among groups (two-way ANOVA followed by Bonferroni's multiple-comparisons test). C, Serum LH and (D) Serum FSH levels 1 week after OVX and estradiol replacement in Lepr ${ }^{\text {lox/lox }}$ ( $n=6$ ) and Vgat-Cre; Lepr ${ }^{\text {lox/lox }}$ ( $n=$ 6) mice. Lowercase letters $a$ and $b$ above the bars indicate statistically significant differences between groups (one-way ANOVA followed by Bonferroni's multiple-comparisons test). Data are shown as mean \pm SEM.

of Kiss 1 and Tac2 in the ARC in the absence of circulating estradiol (Smith et al., 2005a; Kauffman et al., 2009). We found a significantly lower number of Kiss1-expressing neurons in the ARC $\left(160.1 \pm 6.2\right.$ cells; $\left.t_{(4)}=7.90, p=0.0014\right)$ of Vgat-Cre; Lepr $^{\text {lox/lox }}$ females compared with control Lepr $r^{\text {lox/lox }}$ littermates (237.3 \pm 7.5 cells). In contrast, the number of Tac2-expressing cells in the ARC remained unaltered between Vgat-Cre;Lepr $r^{\text {lox } / \text { lox }}$ and control Lepr ${ }^{\text {lox/lox }}$ mice (183.7 \pm 54.6 cells vs $208.3 \pm 23.8$ cells, respectively; $p=$ n.s.; Fig. 6 , left, middle).

In addition, we measured the expression of Kiss 1 mRNA in the AVPV/PeN, a suggested mediator of the positive feedback of E2 in the female (Smith et al., 2005a). We performed these measurements in OVX, E2-replaced mice, based on previous reports indicating maximal expression of Kiss 1 in the AVPV/PeN following estradiol treatment (Smith et al., 2005a). Of note, Tac2 is not expressed in this nucleus (Navarro et al., 2009), and therefore was not assessed in this experiment. We found that the Kiss1 expression in the AVPV was significantly lower in OVX, E2-replaced Vgat-Cre; Lepr ${ }^{\text {lox/lox }}$ females than in control Lepr ${ }^{\text {lox/lox }}$ littermates $\left(120.0 \pm 6.3\right.$ cells vs $146.0 \pm 9.7$ cells, respectively; $t_{(8)}=$ $2.37, p=0.0453$; Fig. 6 , right).

\section{Discussion}

Despite the undeniable influence of leptin signaling in reproduction, the identity of first-order leptin-responsive neurons that regulate reproductive function remains elusive. GnRH neurons do not express leptin receptor (Quennell et al., 2009; Louis et al., 2011), suggesting that leptin acts upstream of GnRH neurons. Moreover, mice with genetic ablation of the leptin receptor in kisspeptin neurons remained fertile (Donato et al., 2011), indi- 
Kiss 1
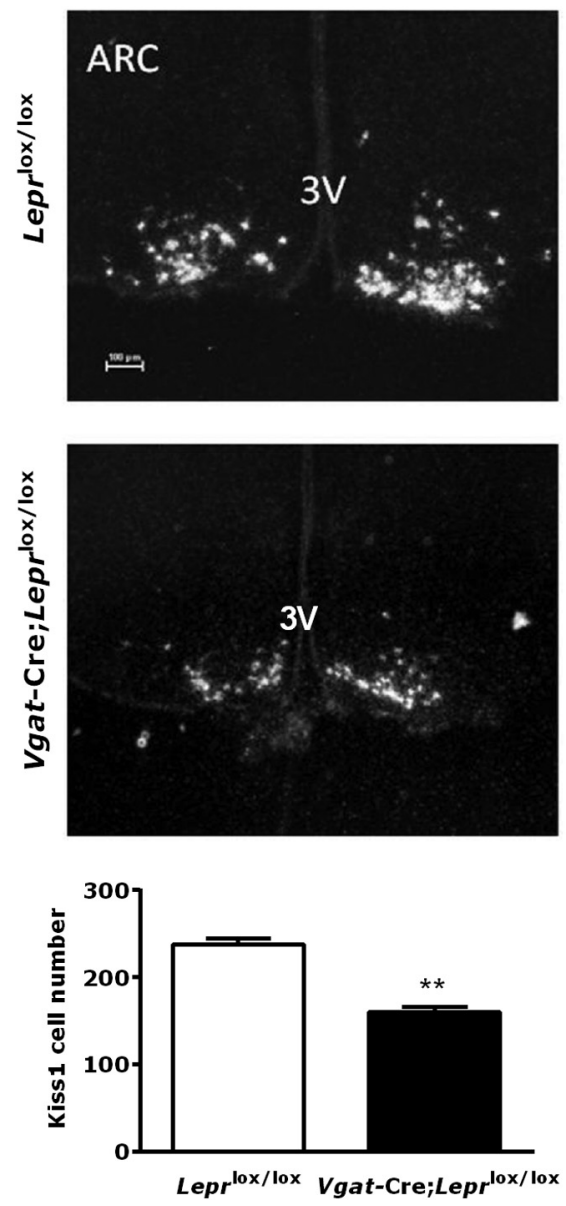

Tac2
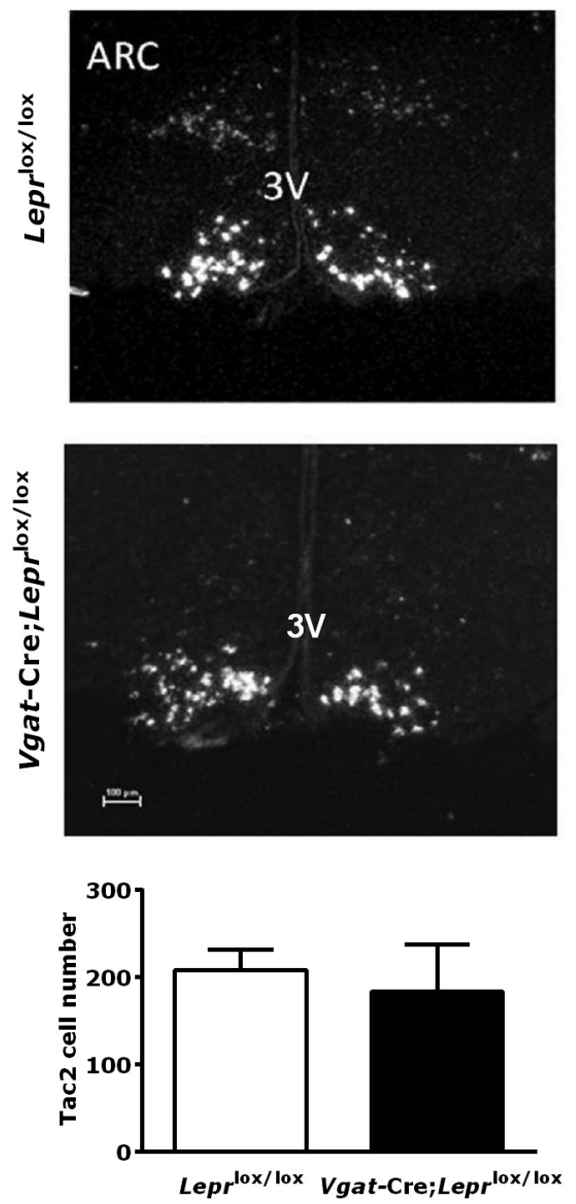

Kiss1
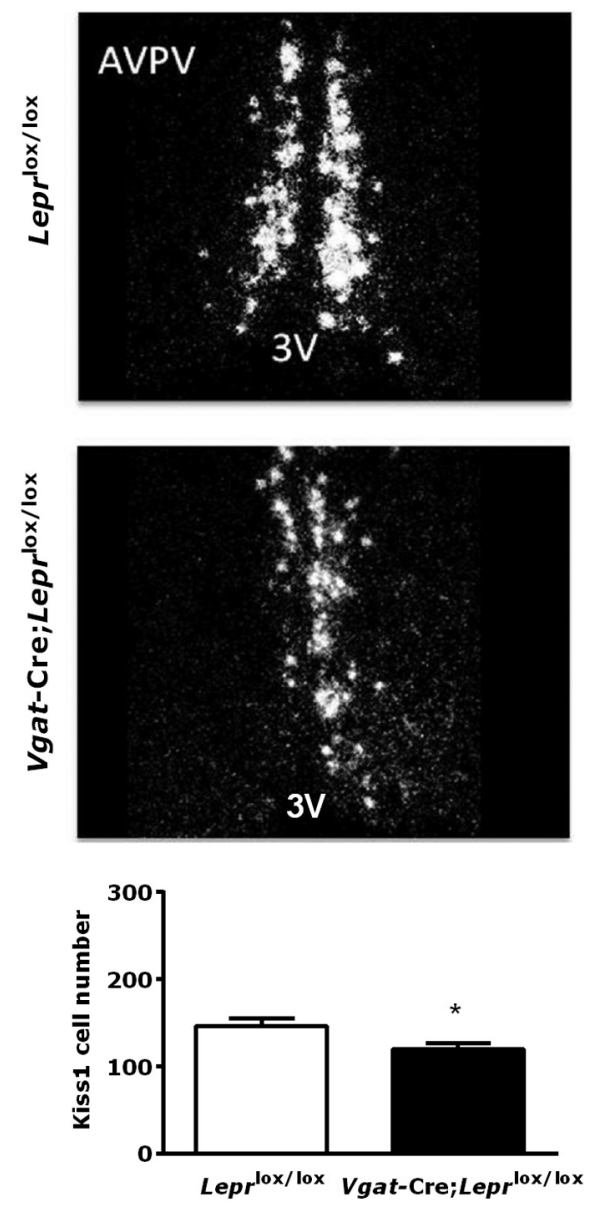

Figure 6. Reduced expression of ARC and AVPV/PeN Kiss1 mRNA, but not ARC Tac2 mRNA, in Vgat-Cre;Lepr lox/lox female mice. mRNA levels of Kiss 1 (left), along with mRNA expression of Tac2 (middle) in the ARC after 1 week ovariectomy, and Kiss 1 (right) in the AVPV/PeN of ovariectomized females treated with $20 \mu \mathrm{g} / \mathrm{ml}$ of estrogen determined by in situ hybridization. A representative microphotograph of control Lepr ${ }^{\text {lox/lox }}$ (top, $n=4$ ) and Vgat-Cre;Lepr ${ }^{\text {lox/lox }}$ (middle, $n=3$ ) mice is shown along with the quantification of positive cell numbers (bottom) for each respective gene. Data are shown as mean $\pm \mathrm{SEM} ;{ }^{*} p=0.0453,{ }^{* *} p=0.0014$ by unpaired $t$ test. Scale bar, $100 \mu \mathrm{m}$.

cating that the reproductive actions of leptin may also lie upstream of kisspeptin neurons. In this work, we present compelling evidence indicating an essential role of GABAergic, but not glutamatergic, neurons in the reproductive role of leptin in females. We found that female mice lacking functional leptin receptors in GABAergic neurons (Vgat-Cre;Lepr ${ }^{\text {lox/lox }}$ mice) have hypogonadotropic hypogonadism, similar to leptin-deficient $(o b / o b)$ and resistant ( $d b / d b)$ mice (Swerdloff et al., 1978; de Luca et al., 2005; Israel and Chua, 2010; Harno et al., 2013). These mice displayed small, immature ovaries and absent corpora lutea, reflecting ovarian failure and anovulation.

Increasing numbers of reports reveal pitfalls in the Cre-lox technology leading to unintended experimental outcomes (Harno et al., 2013). However, it is unlikely that the Vgat-Cre; lepr ${ }^{\text {lox/lox }}$ reproductive phenotype is driven by Cre recombinase expression itself, because heterozygous Vgat-Cre;Lepr ${ }^{\text {lox/WT }}$ females and males are fertile and have a similar body weight to Lepr ${ }^{\text {lox/lox }}$ mice. Together, these observations suggest that the genetic modification itself is not likely to account for the observed phenotype.

A direct (leptin-independent) effect of obesity on fertility must also be considered (Lane and Dickie, 1958; Pasquali et al., 2007). However, previous studies in leptin deficient rodents and humans have shown that weight loss per se is not sufficient to restore reproduction without exogenous leptin administration (Ahima et al., 1996; Chehab et al., 1996; Mounzih et al., 1997; Gonzalez et al., 1999; Farooqi, 2002). Additionally, in our studies, at the age of puberty onset in control mice, all groups had similar body weights, further excluding body weight as the primary contributing factor for their reproductive incompetence. We cannot exclude a potential contribution of the genetic background to the severity of the infertility phenotype (Elias and Purohit, 2013). The $o b / o b$ mice crossed onto a BALB/cJ background have been shown to have a milder reproductive phenotype despite being obese to a similar extent as ob/ob mice in the C57BL/6 background (Ewart-Toland et al., 1999), further supporting the notion that obesity is not a major contributor to the infertile phenotype in leptin-deficient mice (Qiu et al., 2001).

The central deficiency of gonadotropin secretion resulting from a leptin signaling defect (Swerdloff et al., 1978) would be expected to result in insufficient ovarian stimulation during postnatal development, thereby resulting in failure to undergo sexual maturation, i.e., puberty. This is consistent with the phenotype observed in Vgat-Cre;Lepr ${ }^{\text {lox/lox }}$ female mice, which exhibit hypogonadism accompanied by a delay or absence of $\mathrm{VO}$ and absent estrous cycles, in keeping with the reported permissive action of leptin for puberty onset. This suggests that pubertal maturation is mediated, at least in part, via GABAergic neurons 
in the female mouse. While this paper was under review, similar findings were reported (Zuure et al., 2013). Together, these findings demonstrate the critical role of leptin-responsive GABAergic neurons in puberty and fertility.

The onset of puberty requires the reactivation of GnRH neurons (whose embryonic and postnatal development is independent of leptin; Elias, 2012) after a prolonged period of quiescence (Terasawa and Fernandez, 2001). Kisspeptin secretion is essential for pubertal progression (de Roux et al., 2003; Seminara et al., 2003), and changes in kisspeptin tone induce changes in the timing of puberty onset in rodents and humans (Navarro et al., 2004; Silveira et al., 2013). Interestingly, we found that the genetic ablation of leptin receptors in GABAergic neurons compromises the expression of ARC and AVPV Kiss1 mRNA in female mice, consistent with previous reports in ob/ob mice (Smith et al., 2006; Quennell et al., 2011), which may contribute to the absence of puberty onset and lack of estrous cyclicity observed. Kisspeptin has been suggested to play an important role as a conduit of metabolic function to GnRH neurons (Pinilla et al., 2012). First, Kiss 1 expression is significantly reduced in food-deprived rats (Castellano et al., 2005) and in ob/ob mice (Smith et al., 2006) as well as in Zucker ( $f a / f a)$ rats (Navarro et al., 2004). Second, exogenous leptin administration to leptin-deficient rodents increased Kiss 1 expression (Smith et al., 2006), suggesting a higher hierarchical level of leptin action. Consistent with these previous studies, kisspeptin administration to Vgat-Cre;Lepr ${ }^{\text {lox/lox }}$ females in our experiments resulted in robust stimulation of LH release. The ability of these mice to respond to kisspeptin was not only preserved, but also significantly augmented compared with their controls, indicating that GnRH neurons and gonadotropes are intact and able to respond to the kisspeptin stimulus. This effect is reminiscent of the previously reported actions of kisspeptin in conditions of negative energy balance (Castellano et al., 2005). One possible explanation for the hypersensitivity to kisspeptin in Vgat-Cre;Lepr ${ }^{\text {lox/lox }}$ mice is that there is lower constitutive exposure of these animals to kisspeptin, leading to reduced tachyphylaxis of the receptor. Kiss1r expression was similar, but we cannot exclude the possibility that leptin signaling may modify kisspeptin receptors at the protein level, such as by changes in protein synthesis, post-translational modifications, or receptor trafficking.

Kisspeptin neurons mediate sex steroid action upon GnRH release. We observed that Vgat-Cre;Lepr ${ }^{\text {lox/lox }}$ mice still respond to gonadectomy by increasing LH levels and Kiss 1 expression in the ARC, although at a significantly lower level than controls. Moreover, estradiol replacement reduced $\mathrm{LH}$ release in both groups. Of note, the LH levels of estradiol-treated Vgat-Cre; Lepr ${ }^{\text {lox/lox }}$ mice were significantly lower than controls; however, they started from significantly reduced LH levels (as seen in OVX and sham-replaced animals), indicating an overall equivalent magnitude of the inhibitory action of sex steroids. These findings are consistent with the sensitivity to feedback inhibition observed in ob/ob mice (Swerdloff et al., 1976; Batt et al., 1982). Altogether, these data suggest the presence of circulating sex steroids in these animals that are capable of inducing negative feedback, and that other sex-steroid independent factors contribute to the impaired increase in LH following ovariectomy.

Sex steroids also play a critical role in the female to induce ovulation through positive feedback mechanisms that are believed to occur at the level of AVPV kisspeptin neurons (Smith et al., 2005b). Vgat-Cre;Lepr ${ }^{\text {lox/lox }}$ mice had decreased levels of AVPV Kiss1 expression after estradiol replacement. We hypothesize that these reduced levels reflect compromised positive feed- back effects of estradiol, which may suggest impairment in the ovulatory GnRH surges. This hypothesis is supported by the lack of corpora lutea in Vgat-Cre;Lepr ${ }^{\text {lox/lox }}$ mice, indicating anovulation. These findings are also consistent with a previous report of impaired AVPV kisspeptin neuronal activation in response to a $\mathrm{GnRH}$ surge-inducing protocol in a neuron-specific leptin receptor-deficient mouse model (Quennell et al., 2011).

Despite the colocalization of NKB and kisspeptin in the ARC and the stimulatory effects of both neuropeptides on gonadotropin release (Lehman et al., 2010), we found differences in the regulation of Kiss1 and Tac2 expression in the Vgat-Cre;Lepr ${ }^{\text {lox/lox }}$ mice, not seen in their control littermates. Kiss1, but not Tac2, mRNA expression in the ARC was reduced in Vgat-Cre;Lepr ${ }^{\text {lox/lox }}$ OVX females. These findings suggest independent regulatory pathways for these cotransmitters, as previously suggested (Gill et al., 2012).

We have presented a series of physiological and pharmacological studies that unveil a pivotal role of GABAergic neurons in the reproductive actions of leptin. Interestingly, we found a parallelism in the reproductive and metabolic phenotypes of Vgat-Cre; Lepr ${ }^{\text {lox/lox }}$ mice, indicating that leptin action via GABAergic networks reduces the inhibitory tone not only in POMC neurons (obesogenic effect; Vong et al., 2011), but also on upstream circuits impinging on GnRH regulation (Zuure et al., 2013). These unexpected findings may appear contradictory to recent studies that identified the ventral premammillary nucleus (PMV), predominantly populated by glutamatergic (excitatory) neurons, as direct reproductive targets of leptin action (Donato et al., 2011). However, it is important to consider developmental adaptations that may result from the removal of leptin-responsive GABAergic neurons to disrupt the balance of excitatory and inhibitory inputs to GnRH neurons (Elias and Purohit, 2013). Further investigation is needed to fully elucidate the contribution of PMV neurons as major integrators of metabolic influence on reproductive function. The GABA-mediated contribution to the permissive role of leptin for reproduction is consistent with previous reports in the monkey suggesting that a prepubertal decrease in GABAergic tone precedes the reawakening of $\mathrm{GnRH}$ pulses at the time of puberty onset, mediated at least in part, by kisspeptin neurons (Kurian et al., 2012). The future identification of the leptinresponsive GABAergic neurons will further improve our understanding of the nature of this reproductive/metabolic circuit.

In summary, the present work expands our knowledge of the mechanism of action of leptin to regulate reproductive function. This action is predominantly mediated by GABAergic neurons, possibly as result of decreased inhibitory GABAergic output in response to leptin signaling. In contrast, the role of leptinresponsive glutamatergic neurons (with predominantly stimulatory actions) appears secondary, perhaps involved in fine-tuning control of kisspeptin and/or GnRH release. Our findings strongly suggest that the reduction of the inhibitory tone necessary for the progression to puberty is disrupted in Vgat-Cre;Lepr ${ }^{\text {lox/lox }}$ mice, and that this effect is mediated, at least in part, through modulatory effects on kisspeptin neurons.

\section{References}

Ahima RS, Prabakaran D, Mantzoros C, Qu D, Lowell B, Maratos-Flier E, Flier JS (1996) Role of leptin in the neuroendocrine response to fasting. Nature 382:250-252. CrossRef Medline

Balthasar N, Coppari R, McMinn J, Liu SM, Lee CE, Tang V, Kenny CD, McGovern RA, Chua SC Jr, Elmquist JK, Lowell BB (2004) Leptin receptor signaling in POMC neurons is required for normal body weight homeostasis. Neuron 42:983-991. CrossRef Medline

Barash IA, Cheung CC, Weigle DS, Ren H, Kabigting EB, Kuijper JL, Clifton 
DK, Steiner RA (1996) Leptin is a metabolic signal to the reproductive system. Endocrinology 137:3144-3147. CrossRef Medline

Batt RA, Everard DM, Gillies G, Wilkinson M, Wilson CA, Yeo TA (1982) Investigation into the hypogonadism of the obese mouse (genotype ob/ ob). J Reprod Fertil 64:363-371. CrossRef Medline

Brown RE, Wilkinson DA, Imran SA, Caraty A, Wilkinson M (2012) Hypothalamic kiss $1 \mathrm{mRNA}$ and kisspeptin immunoreactivity are reduced in a rat model of polycystic ovary syndrome (PCOS). Brain Res 1467:1-9. CrossRef Medline

Castellano JM, Navarro VM, Fernández-Fernández R, Nogueiras R, Tovar S, Roa J, Vazquez MJ, Vigo E, Casanueva FF, Aguilar E, Pinilla L, Dieguez C, Tena-Sempere M (2005) Changes in hypothalamic KiSS-1 system and restoration of pubertal activation of the reproductive axis by kisspeptin in undernutrition. Endocrinology 146:3917-3925. CrossRef Medline

Chehab FF (2000) Leptin as a regulator of adipose mass and reproduction. Trends Pharmacol Sci 21:309-314. CrossRef Medline

Chehab FF, Lim ME, Lu R (1996) Correction of the sterility defect in homozygous obese female mice by treatment with the human recombinant leptin. Nat Genet 12:318-320. CrossRef Medline

Cheung CC, Thornton JE, Kuijper JL, Weigle DS, Clifton DK, Steiner RA (1997) Leptin is a metabolic gate for the onset of puberty in the female rat. Endocrinology 138:855-858. CrossRef Medline

Cohen P, Zhao C, Cai X, Montez JM, Rohani SC, Feinstein P, Mombaerts P, Friedman JM (2001) Selective deletion of leptin receptor in neurons leads to obesity. J Clin Invest 108:1113-1121. CrossRef Medline

Coleman DL (1978) Obese and diabetes: two mutant genes causing diabetes-obesity syndromes in mice. Diabetologia 14:141-148. CrossRef Medline

de Luca C, Kowalski TJ, Zhang Y, Elmquist JK, Lee C, Kilimann MW, Ludwig T, Liu SM, Chua SC Jr (2005) Complete rescue of obesity, diabetes, and infertility in $d b / d b$ mice by neuron-specific LEPR-B transgenes. J Clin Invest 115:3484-3493. CrossRef Medline

de Roux N, Genin E, Carel JC, Matsuda F, Chaussain JL, Milgrom E (2003) Hypogonadotropic hypogonadism due to loss of function of the KiSS1derived peptide receptor GPR54. Proc Natl Acad Sci U S A 100:1097210976. CrossRef Medline

Donato J Jr, Cravo RM, Frazão R, Gautron L, Scott MM, Lachey J, Castro IA, Margatho LO, Lee S, Lee C, Richardson JA, Friedman J, Chua S Jr, Coppari R, Zigman JM, Elmquist JK, Elias CF (2011) Leptin's effect on puberty in mice is relayed by the ventral premammillary nucleus and does not require signaling in Kiss1 neurons. J Clin Invest 121:355-368. CrossRef Medline

Elias CF (2012) Leptin action in pubertal development: recent advances and unanswered questions. Trends Endocrinol Metab 23:9-15. CrossRef Medline

Elias CF, Purohit D (2013) Leptin signaling and circuits in puberty and fertility. Cell Mol Life Sci 70:841-862. CrossRef Medline

Ewart-Toland A, Mounzih K, Qiu J, Chehab FF (1999) Effect of the genetic background on the reproduction of leptin-deficient obese mice. Endocrinology 140:732-738. CrossRef Medline

Farooqi IS (2002) Leptin and the onset of puberty: insights from rodent and human genetics. Semin Reprod Med 20:139-144. CrossRef Medline

Frisch RE (1985) Fatness, menarche, and female fertility. Perspect Biol Med 28:611-633. Medline

Furuta M, Funabashi T, Kimura F (2001) Intracerebroventricular administration of ghrelin rapidly suppresses pulsatile luteinizing hormone secretion in ovariectomized rats. Biochem Biophys Res Commun 288: 780-785. CrossRef Medline

Gill JC, Navarro VM, Kwong C, Noel SD, Martin C, Xu S, Clifton DK, Carroll RS, Steiner RA, Kaiser UB (2012) Increased neurokinin B (Tac2) expression in the mouse arcuate nucleus is an early marker of pubertal onset with differential sensitivity to sex steroid-negative feedback than Kiss1. Endocrinology 153:4883-4893. CrossRef Medline

Gonzalez LC, Pinilla L, Tena-Sempere M, Aguilar E (1999) Leptin(116130) stimulates prolactin and luteinizing hormone secretion in fasted adult male rats. Neuroendocrinology 70:213-220. CrossRef Medline

Gottsch ML, Cunningham MJ, Smith JT, Popa SM, Acohido BV, Crowley WF, Seminara S, Clifton DK, Steiner RA (2004) A role for kisspeptins in the regulation of gonadotropin secretion in the mouse. Endocrinology 145:4073-4077. CrossRef Medline

Harno E, Cottrell EC, White A (2013) Metabolic pitfalls of CNS Cre-based technology. Cell Metab 18:21-28. CrossRef Medline
Holtkamp K, Mika C, Grzella I, Heer M, Pak H, Hebebrand J, HerpertzDahlmann B (2003) Reproductive function during weight gain in anorexia nervosa: leptin represents a metabolic gate to gonadotropin secretion. J Neural Transm 110:427-435. CrossRef Medline

Israel D, Chua S Jr (2010) Leptin receptor modulation of adiposity and fertility. Trends Endocrinol Metab 21:10-16. CrossRef Medline

Kauffman AS, Navarro VM, Kim J, Clifton DK, Steiner RA (2009) Sex differences in the regulation of Kiss1/NKB neurons in juvenile mice: implications for the timing of puberty. Am J Physiol Endocrinol Metab 297: E1212-1221. CrossRef Medline

Kurian JR, Keen KL, Guerriero KA, Terasawa E (2012) Tonic control of kisspeptin release in prepubertal monkeys: implications to the mechanism of puberty onset. Endocrinology 153:3331-3336. CrossRef Medline

Lane PW, Dickie MM (1958) The effect of restricted food intake on the life span of genetically obese mice. J Nutr 64:549-554. Medline

Lehman MN, Coolen LM, Goodman RL (2010) Minireview: kisspeptin/ neurokinin B/dynorphin (KNDy) cells of the arcuate nucleus: a central node in the control of gonadotropin-releasing hormone secretion. Endocrinology 151:3479-3489. CrossRef Medline

Louis GW, Greenwald-Yarnell M, Phillips R, Coolen LM, Lehman MN, Myers MG Jr (2011) Molecular mapping of the neural pathways linking leptin to the neuroendocrine reproductive axis. Endocrinology 152:23022310. CrossRef Medline

Mantzoros CS, Magkos F, Brinkoetter M, Sienkiewicz E, Dardeno TA, Kim SY, Hamnvik OP, Koniaris A (2011) Leptin in human physiology and pathophysiology. Am J Physiol Endocrinol Metab 301:E567-E584. CrossRef Medline

McMinn JE, Liu SM, Dragatsis I, Dietrich P, Ludwig T, Eiden S, Chua SC Jr (2004) An allelic series for the leptin receptor gene generated by CRE and FLP recombinase. Mamm Genome 15:677-685. CrossRef Medline

Meyers EN, Lewandoski M, Martin GR (1998) An Fgf8 mutant allelic series generated by Cre- and Flp-mediated recombination. Nat Genet 18:136141. CrossRef Medline

Mounzih K, Lu R, Chehab FF (1997) Leptin treatment rescues the sterility of genetically obese ob/ob males. Endocrinology 138:1190-1193. CrossRef Medline

Navarro VM, Fernández-Fernández R, Castellano JM, Roa J, Mayen A, Barreiro ML, Gaytan F, Aguilar E, Pinilla L, Dieguez C, Tena-Sempere M (2004) Advanced vaginal opening and precocious activation of the reproductive axis by KiSS-1 peptide, the endogenous ligand of GPR54. J Physiol 561:379-386. CrossRef Medline

Navarro VM, Gottsch ML, Chavkin C, Okamura H, Clifton DK, Steiner RA (2009) Regulation of gonadotropin-releasing hormone secretion by kisspeptin/dynorphin/neurokinin B neurons in the arcuate nucleus of the mouse. J Neurosci 29:11859-11866. CrossRef Medline

Pasquali R, Patton L, Gambineri A (2007) Obesity and infertility. Curr Opin Endocrinol Diabetes Obes 14:482-487. CrossRef Medline

Pinilla L, Aguilar E, Dieguez C, Millar RP, Tena-Sempere M (2012) Kisspeptins and reproduction: physiological roles and regulatory mechanisms. Physiol Rev 92:1235-1316. CrossRef Medline

Qiu J, Ogus S, Mounzih K, Ewart-Toland A, Chehab FF (2001) Leptindeficient mice backcrossed to the BALB/CJ genetic background have reduced adiposity, enhanced fertility, normal body temperature, and severe diabetes. Endocrinology 142:3421-3425. CrossRef Medline

Quennell JH, Mulligan AC, Tups A, Liu X, Phipps SJ, Kemp CJ, Herbison AE, Grattan DR, Anderson GM (2009) Leptin indirectly regulates gonadotropin-releasing hormone neuronal function. Endocrinology 150: 2805-2812. CrossRef Medline

Quennell JH, Howell CS, Roa J, Augustine RA, Grattan DR, Anderson GM (2011) Leptin deficiency and diet-induced obesity reduce hypothalamic kisspeptin expression in mice. Endocrinology 152:1541-1550. CrossRef Medline

Schreihofer DA, Amico JA, Cameron JL (1993) Reversal of fasting-induced suppression of luteinizing hormone (LH) secretion in male rhesus monkeys by intragastric nutrient infusion: evidence for rapid stimulation of LH by nutritional signals. Endocrinology 132:1890-1897. CrossRef Medline

Seminara SB, Messager S, Chatzidaki EE, Thresher RR, Acierno JS Jr, Shagoury JK, Bo-Abbas Y, Kuohung W, Schwinof KM, Hendrick AG, Zahn D, Dixon J, Kaiser UB, Slaugenhaupt SA, Gusella JF, O'Rahilly S, Carlton MB, Crowley WF Jr, Aparicio SA, Colledge WH (2003) The GPR54 gene as a regulator of puberty. $\mathrm{N}$ Engl J Med 349:1614-1627. CrossRef Medline 
Silveira LG, Latronico AC, Seminara SB (2013) Kisspeptin and clinical disorders. Adv Exp Med Biol 784:187-199. CrossRef Medline

Singh SP, Wolfe A, Ng Y, DiVall SA, Buggs C, Levine JE, Wondisford FE, Radovick S (2009) Impaired estrogen feedback and infertility in female mice with pituitary-specific deletion of estrogen receptor alpha (ESR1). Biol Reprod 81:488-496. CrossRef Medline

Smith JT, Dungan HM, Stoll EA, Gottsch ML, Braun RE, Eacker SM, Clifton DK, Steiner RA (2005a) Differential regulation of KiSS-1 mRNA expression by sex steroids in the brain of the male mouse. Endocrinology 146: 2976-2984. CrossRef Medline

Smith JT, Cunningham MJ, Rissman EF, Clifton DK, Steiner RA (2005b) Regulation of Kiss1 gene expression in the brain of the female mouse. Endocrinology 146:3686-3692. CrossRef Medline

Smith JT, Acohido BV, Clifton DK, Steiner RA (2006) KiSS-1 neurones are direct targets for leptin in the $o b / o b$ mouse. J Neuroendocrinol 18:298303. CrossRef Medline

Swerdloff RS, Batt RA, Bray GA (1976) Reproductive hormonal function in the genetically obese $(o b / o b)$ mouse. Endocrinology 98:1359-1364. CrossRef Medline
Swerdloff RS, Peterson M, Vera A, Batt RA, Heber D, Bray GA (1978) The hypothalamic-pituitary axis in genetically obese $(\mathrm{ob} / \mathrm{ob})$ mice: response to luteinizing hormone-releasing hormone. Endocrinology 103:542-547. CrossRef Medline

Terasawa E, Fernandez DL (2001) Neurobiological mechanisms of the onset of puberty in primates. Endocr Rev 22:111-151. CrossRef Medline

van Herck H, Baumans V, Brandt CJ, Hesp AP, Sturkenboom JH, van Lith HA, van Tintelen G, Beynen AC (1998) Orbital sinus blood sampling in rats as performed by different animal technicians: the influence of technique and expertise. Lab Anim 32:377-386. CrossRef Medline

Vong L, Ye C, Yang Z, Choi B, Chua S Jr, Lowell BB (2011) Leptin action on GABAergic neurons prevents obesity and reduces inhibitory tone to POMC neurons. Neuron 71:142-154. CrossRef Medline

Welt CK, Chan JL, Bullen J, Murphy R, Smith P, DePaoli AM, Karalis A, Mantzoros CS (2004) Recombinant human leptin in women with hypothalamic amenorrhea. N Engl J Med 351:987-997. CrossRef Medline

Zuure WA, Roberts AL, Quennell JH, Anderson GM (2013) Leptin signaling in GABA neurons, but not glutamate neurons, is required for reproductive function. J Neurosci 33:17874-17883. CrossRef Medline 